Meta

Journal des traducteurs

Translators' Journal

\title{
From the Dutch corantos to Convergence Journalism: The Role of Translation in News Production
}

\section{Roberto A. Valdeón}

Volume 57, numéro 4, décembre 2012

Journalisme et traduction

Journalism and Translation

URI : https://id.erudit.org/iderudit/1021221ar

DOI : https://doi.org/10.7202/1021221ar

Aller au sommaire du numéro

Éditeur(s)

Les Presses de l’Université de Montréal

ISSN

0026-0452 (imprimé)

1492-1421 (numérique)

Découvrir la revue

Citer cet article

Valdeón, R. A. (2012). From the Dutch corantos to Convergence Journalism: The Role of Translation in News Production. Meta, 57(4), 850-865.

https://doi.org/10.7202/1021221ar

\section{Résumé de l'article}

Le présent article offre un aperçu du rôle de la traduction dans la diffusion de nouvelles depuis l'arrivée du journalisme jusqu'au XxI ${ }^{\mathrm{e}}$ siècle. L'accent est mis sur la manière dont les nouvelles sont traduites au cours de trois périodes, c'est-à-dire : (1) les XVII ${ }^{\mathrm{e}}$ et XVIII ${ }^{\mathrm{e}}$ siècles en Europe, époque de la naissance des premiers journaux, particulièrement en Angleterre, en Espagne et en Scandinavie, où la plupart des premiers pamphlets publiés sont traduits ; (2) à partir de la fin du XIX ${ }^{\mathrm{e}}$ siècle, alors que la relation entre les langues et la traduction se montre toujours présente dans le travail des correspondants à l'étranger, bien que de façon souvent invisible ; (3) à l'époque de la professionnalisation du journalisme, alors que l'importance de la traduction se reflète dans le besoin des journalistes de recevoir une formation en langues étrangères ainsi que dans la percée de nouvelles agences où la traduction est l'une des activités principales. Enfin, l'arrivée et la diffusion massive d'Internet ont rendu le rôle de la traduction encore plus apparent, même si elle demeure une activité invisible et secondaire dans le processus de production des nouvelles.
Ce document est protégé par la loi sur le droit d'auteur. L'utilisation des services d'Érudit (y compris la reproduction) est assujettie à sa politique d'utilisation que vous pouvez consulter en ligne.

https://apropos.erudit.org/fr/usagers/politique-dutilisation/ 


\title{
From the Dutch corantos to Convergence Journalism: The Role of Translation in News Production
}

\author{
ROBERTO A. VALDEÓN \\ Universidad de Oviedo, Oviedo, Spain \\ University of Leuven, Leuven, Belgium \\ valdeon@uniovi.es
}

\section{RÉSUMÉ}

Le présent article offre un aperçu du rôle de la traduction dans la diffusion de nouvelles depuis l'arrivée du journalisme jusqu'au $x x^{e}{ }^{e}$ siècle. L'accent est mis sur la manière dont les nouvelles sont traduites au cours de trois périodes, c'est-à-dire: (1) les $X_{V I I}{ }^{e}$ et $X V I I I^{e}$ siècles en Europe, époque de la naissance des premiers journaux, particulièrement en Angleterre, en Espagne et en Scandinavie, où la plupart des premiers pamphlets publiés sont traduits; (2) à partir de la fin du $x_{1} x^{e}$ siècle, alors que la relation entre les langues et la traduction se montre toujours présente dans le travail des correspondants à l'étranger, bien que de façon souvent invisible; (3) à l'époque de la professionnalisation du journalisme, alors que l'importance de la traduction se reflète dans le besoin des journalistes de recevoir une formation en langues étrangères ainsi que dans la percée de nouvelles agences où la traduction est l'une des activités principales. Enfin, l'arrivée et la diffusion massive d'Internet ont rendu le rôle de la traduction encore plus apparent, même si elle demeure une activité invisible et secondaire dans le processus de production des nouvelles.

\begin{abstract}
This article provides a overview of the role translation has played in news transmission since the birth of journalism until the 21st century. The paper focuses on three periods and the ways in which translation has been present in news production: (1) translation at the origin of newspapers in 17th- and 18th-century Europe, with particular reference to England, Spain and Scandinavia, where translation was, in fact, the staple diet of the first pamphlets published in those countries, (2) from the late 19th century onwards, the interplay between language and translation has also been present in the activity of foreign correspondents, albeit often in a very invisible manner, and (3) as the journalistic activity was professionalized, the importance of translation can be traced in the need for journalists to be trained in foreign languages as well as in the appearance of news agencies whose activity is to a great extent translational. Finally, the advent and spread of the Internet has made the role of translation more apparent, even if it remains an invisible second-rate activity within the news production process.
\end{abstract}

\section{MOTS-CLÉS/KEYWORDS}

nouvelles (actualités), journalisme, périodique, agence de nouvelles, correspondant étranger

news, journalism, periodical, news agency, foreign correspondent 


\section{Introduction}

Two books published in 2009 analyzed the role of translation in news production. Bielsa and Bassnett studied translation in international news agencies, whereas Hernández Guerrero offered an insight into the use of translation in Spain's most important newspapers. The second edition of the Routledge Encyclopedia of Translation Studies and John Benjamins' Handbook of Translation Studies include entries devoted to "news gathering and dissemination" (Palmer 2009: 186-188) and "journalism and translation" (van Doorslaer 2010: 180-184) respectively. In 2010 a special issue of Across Languages and Cultures was devoted to "Translation in the Post-Industrialist Society" (Valdeón 2010) with particular reference to the transfer of information into other languages, its peculiarities and conventions. More recently, Bellos, a literary translator and a professor at Princeton, devoted a section of his recently published book to news translation (Bellos 2011: 241-246), signalling the central role of the activity in news dissemination. The importance of translation within the journalistic profession can be summarized using Bellos's very visual style: "even if a hypothetical global news translation HQ [headquarter] served only 80 vehicular languages, it would still require 6,320 different language desks" (Bellos 2011: 242). In other words, news translators might be invisible but their activity no longer is.

However, translation has scarcely featured in studies of journalistic production or history. For instance, in his 1995 analysis of foreign correspondents, Hohenberg offers a historic approach to the profession and its risks where translation is barely mentioned, even though, as we shall see in the next section, translation has always been a part of the process of communicating foreign news events to the readers. Hohenberg recalls the report of the assassination of the Archduke in Sarajevo published in The New York Times, which was based on "the translated account of the Vienna Neue Freie Presse, with other details from the London Daily Mail" (Hohenberg 1995: 85). This passing remark emphasizes the role of translation as an intrinsic part of the news production process alongside other sources: translating and recycling information, which will also be dealt with further down, have thus been at the core of journalism from its inception as a profession back in the 18th century, when the knowledge of other languages and cultures was considered fundamental for wouldbe journalists. As Bainbridge indicates, a sound knowledge of English, geography and languages (Latin, French and German) was required during the first attempts to professionalize the job (Bainbridge 1984: 55). But this has not always been recognized by the profession.

In fact, it was not until the first decade of the 21st century that a number of translation scholars gradually became concerned with the work of news translators. They have approached the issue from different perspectives and considered the various media (i.e., Tsai 2006 and Conway 2010 have worked on television content; van Doorslaer 2009 has worked on newspapers). But, although the borderlines between news and translation as an area of study may have been crossed fairly recently (van Doorslaer 2010: 180), the connection between news and translation can be traced back to the birth of journalism itself. And yet translation has rarely been accounted for within Journalism Studies, let alone given any relevance as part of the news production process, even in the case of foreign news and foreign correspondents. Only recently have media scholars considered the role of translation in news production 
and dissemination. In 2011, a special issue of Journalism was devoted to the politics of translation in the BBC World Service. The guest editors, who acknowledged that media studies have been slow to deal with translational issues (Baumann, Gillespie et al. 2011: 135), and no mention is made of the greater number of publications concerning news translation authored by translation scholars other than a reference to the proceedings of a conference held in Warwick, UK (Conway and Bassnett 2006). Baumann, Gillespie et al. acknowledge the relevance of translation within the news production process as the "translating journalists," as they call text producers (Baumann, Gillespie et al. 2011: 136), have greater freedom and editorial control over the material they produce. After all, the huge number of texts journalists currently create can escape the scrutiny of media owners and politicians more easily than in the early years of journalism, when newspapers were closely monitored by governments and companies. In addition to this, and echoing Sabir Mustafa, the head of the Bengali service of the BBC, Podkalicka has referred to news companies where translation is the main activity as translation factories (Podkalicka 2011: 146).

The next sections explore the complex connections between news dissemination, languages and translation from the 17th century onwards. They focus on the evolution of the role of translation over the centuries: the linguistic and cultural transformations carried out in 17th- and 18th-century Europe as a result of an interest in foreign news, the importance of languages in the 19th century as newspapers hired foreign correspondents and, finally, the industrialization process, which Fishman (1980) has called "news manufacturing," present in news agencies from the late 19th century onwards. The paper will conclude with some remarks about how the Internet has brought translation to the fore, even though it largely remains an invisible activity. In fact, it is much more so than literary or technical translation, except in the few cases where the producers of the texts assert their rights as authors (discussed in this issue, for example, by Hernández Guerrero).

\section{A historic review of translation and journalism}

Talking about the poet Robert Browning's trips in Europe back in 1838, Bellos points out that in the past the most likely way to receive news in the old continent was likely to be in French (Bellos 2011: 241). However, well before the 19th century, at the very outset of journalism, translation was already an integral part of the profession. Journalism, let us bear in mind, was regarded as a second-rate trade, an option for unworthy writers. Harris recalls that the "practice of journalism, particularly in politics, continued to be regarded as one of the least respectable forms of literary activity" (Harris 1987: 111) and in "the major news-carrying papers, in which the role of the author was restricted largely to the menial tasks of translating and newsgathering" (Harris 1987: 112).

Clarke recalls the role of Daniel Defoe as a journalist, which partly meant writing pamphlets in support of the political parties of his time, partly translating (Clarke 2004: 46-48). Clarke points out that Defoe "started his career in journalism by writing pamphlets loyal to the Whig cause" (Clarke 2004: 46-47), but underlines his ability to be of service to both Whigs and Tories. Defoe offered his services to Nathaniel Mist, editor of the Weekly Journal "in the disguise of a translator of the foreign news" (Clarke 2004: 48) and his role was to tone down the attacks on the 
government. Defoe benefited from his knowledge of foreign languages to manipulate the texts published in other countries. Thus he could support the party of his choice.

Before Defoe's political writings for the Weekly Journal, journalism had been linked to the thirst for news of wars and disasters. Dooley and Baron (2001) point out that the Thirty Years War was at the origins of journalism. The conflict originated as a religious war during which countries changed sides on several occasions, often for economic and political reasons. England received news from continental Europe in the form of pamphets, originally written in Dutch:

Printed news reports of the war in the form of gazettes, or corantos (often rendered as 'currents' by contemporaries) began to be imported into England from the Low Countries from the outset of hostilities in 1618. The corantos were single-sheet broadsheets printed in Dutch, (Dooley and Baron 2001: 17)

or, as Brownlees puts it, in Low German (Brownlees 2006: 9). Because readers were unable to read that language, they "soon began to get translation of the corantos' contents reported in manuscript newsletters [...] London Stationers set out the first English translations in 1620-21" (Dooley and Baron 2001: 17-18). Thus, the English version of the corantos did not carry much news about England. They were factual and with little editorial comment, mostly about continental Europe (Brownlees 2006: 9). As a consequence of these two facts, their popularity declined throughout the years. Additionally, Dooley and Baron remind us that these pamphlets "were closely monitored by the Privy Council, and were suspended completely between 1632 and 1638" (Dooley and Baron 2001: 18). Translation was an instrument of manipulation of source texts. If the translated versions did not meet the expectations of the governments the publication was cancelled altogether.

Freedom of the press did not characterize 17th century England. The two main publications of the late 17th century were the London Gazette and The Present State of Europe; or, the Historical and Political Monthly Mercury, "which was started in in July 1690 and reprinted in Edinburgh and Dublin" (Clarke 2004: 35). The most significant feature of the lattter was that, once again, it was fundamentally a translation from Dutch originals. Their texts provided an image of other European nations through linguistic and cultural transformations. Clarke notes some curious facts concerning the translational activity that characterized these publications. For example, "six pages of the issue for August 1692, under the heading 'Advices from Rome and Italy,' were given over entirely to a text of a Papal Bull printed in Latin, with a further six pages taken up by the English translation, 'for the satisfaction of the Curious"' (Clarke 2004: 35). One can hardly imagine a reason for the decision to include papal bulls other than to create an anti-Catholic mindset among its readership. These translations were censored and references to England and English politics were omitted.

In fact, some argue that the other publication mentioned above, the Gazette, was expected to put pressure on the English against the Dutch or "inflame all England against the Dutch" (O’Malley 1986: 34). This process should be understood as part of the national and empire-building process of the times: texts had to be carefully written to agitate the English against their European neighbours. O'Malley recalls some of the incidents concerning the journal in the last part of the 17th century as the images of the Other (or hetero-images, as Beller and Leerssen call them [Beller 
and Leerssen 2007: xIV]) were being promoted, not always very successfully. For instance, in 1673 M.P.s expressed their anger at a report in the Gazette from Holland. It was suggested that some of them were negotiating with the Dutch while Parliament was not sitting.

For a long period the Gazette was also published in French. Bourne recalls that this version got entangled in some controversy:

Down to 1696 at any rate, a version of the Gazette was issued in French - Gazette de Londres, 'publiée avec privilège.' In 1678, as appears in the Commons' Journal, the printer got into trouble by mistranslating an important passage about popish recusants. (Bourne 1887a: 41)

Monsieur Moranville, the man who translated the Gazette, was arrested and brought before the Commons. He was accused of mistranslating one of the royal proclamations related to the Popish Plot, thus promoting negative images of the English within and outside the country (O'Malley 1986: 34). As O’Malley reminds us, “The Gazette was part of a general attempt by the late Stuart regime to control the flow of information to the reading public" (O’Malley 1986: 34) although he claims that this was not necessarily negative in the sense that they control adequate information "from safe orthodox sources" (O'Malley 1986: 34).

Before the 17th century was out a new publication came to exist, The Evening Standard. In its early years, and partly due to

[F]ears that legislation controlling the press would be re-introduced (attempts were made to re-introduce licensing in 1697, 1698, 1702, 1704 and 1712), the tri-weekly post of the first decade of the 18th century played very safe. (Clarke 2004: 42)

This meant that most of the texts published originated in continental Europe and little space was devoted to national news. But who carried out these linguistic transformations? Clarke mentioned two bilingual Huguenots, Boyer and de Fonvive, who had fled persecution in the continent and had settled in England. Translations continued to be the staple diet of the next journalistic venture, The Daily Courant, the first successful English daily: "The first number of The Daily Courant, dated 11 March 1702, consisted solely of translations of one French paper and two Dutch papers. It was as if nothing had changed since the days of Bourne, Butter and Archer" (Clarke 2004: 42).

As we moved further into the 18th century, newspapers relied less on foreign news, as the country was no longer at war "and foreign news being costly in translation fees, there was little news to report” (Clarke 2004: 49). This, added to the taxes introduced by the government, would lead to a certain decline of the incipient industry. However, translation remained connected to the future of journalism, as the majority of the daily publications, as well as the "thrice-weeklies" (Harris 1987: 159), hired translators to tranfer the material coming from the Continent into English. Although their work "may have involved translating original correspondence, the bulk of the duties were probably made up of handling items from the foreign press" (Harris 1987: 159). In fact, Harris argues, the Dutch reports provided the English readership with more complete information about their own nation than local publications since the lack of freedom in the country did not allow London papers to take risks (Harris 1987: 159).

The translational activity was not only limited to foreign news. Some publications also provided their readers with English versions of foreign fiction. For 
example, in the 1720s the Original Weekly Journal offered a supplement with foreign stories. On the other hand, some early newspapers even had a pedagogical objective, such as the British Mercury, which was rendered into French "for the easier acquiring of the French tongue," and the Weekly Medley, whose text in French and English made it "very useful for schools" that taught this language (Harris 1987: 194). And, perhaps as Conboy suggests, the translation of foreign texts also depended on the fact that news from Europe tended to be more sensationalist, more entertaining (Conboy 2004: 24).

So far we have dealt with translation and journalism in England, but the thirst for news, foreign and national, was also present in other European countries. Ettinghausen underlines that from the Golden Age onwards the need for news was also a characteristic of Spain (Ettinghausen 2001: 199). Initially the news was brought to the country through regular postal services, which provided individuals with information and, then, they "could, in their turn, further disseminate it in their correspondence, while publishers could spread it, near and far, in printed news sheets in prose or in verse which could in turn be reprinted elsewhere, if necessary in translation" (Ettinghausen 2001: 199). The Spanish War of Succession, for instance, was widely reported. Once again a war was responsible for a need for news, the same as it is today (Fawcett 2002). In Catalonia gazettes translated from French into Catalan were published in 1641 and 1642 (Ettinghausen 2001: 202).

Translation was also at the base of journalistic ventures in other parts of the continent. In Scandinavia the first newspapers appeared in the mid-17th century: in 1645 in Sweden and in 1657 in Denmark, whereas Norway and Finland did not have their own news publications until the 18th century, as a consequence of their colonial situation (Høyer 2003: 456). Once again the content of this first publication was transferred from foreign papers (Høyer 2003: 461), as is the case of the Berlingske, whose content was "typically collected from foreign Gazettes and translated into Danish” (Høyer 2003: 456).

Translators were among the first staff members of Swedish papers as well (Høyer 2003: 457). The Ordinari Post-Tijdender, one of the first newspapers on the continent, depended heavily on translations from foreign sources. Ries recalls that the post arrived from Germany on Fridays. Translators or editors had to transfer the information from German into Swedish before the paper came out on Wednesdays "so there would be ample time in which to complete the entire elaborate process - selection, translation, censorship, and printing" (Ries 2001: 242). Translation, as in England, also allowed the editors to manipulate the information to comply with the existing censorship in the area (Ries 2001: 241-247,263). The Ordinari Post-Tijdender had been commissioned by the Swedish government itself (Bandle 2005: 1355), which had no interest in spreading domestic news. It reported on the Thirty Years' War and when it came to an end, the newspaper ceased to be published. As is the case with most other newspapers of the period, the translations published by this paper are difficult, if not impossible, to assess because there are few remaining copies of the originals and their translated versions (Ries 2001: 243). Thus, we cannot draw reliable conclusions from the strategies used during the editing process, i.e., omissions, additions or reductions of the original content (Ries 2001: 243). This is the same terminology used when discussing the transformation of contemporary news texts. 
Another successful Scandinavian newspaper, the Extraordinaires Maanedlige Relationer, was published in Denmark. According to Ries, in January 1673 its contents were for the most part translations: out of forty-seven news items

[...] forty-three were translations into Danish [...] twenty-two of those news items are literal translations, whereas the remaining twenty-one are reformulations, updates, extensions, or summaries of between three and thirteen items about important events covered at various stages during the past month and, most important, because it has been possible to identify his sources for all of them. (Ries 2001: 253)

It is indeed remarkable that Ries has been able to trace each of the forty-three reports in the Extraordinaires Maanedlige Relationer for January 1673, while in contemporary news translation scholarship it is often impossible to locate the source texts of what is clearly a translation. Ries writes that it is easy

[...] to see how the editor decided to dress the "nudam puellam" of the original

Hamburg report, first in his own German version in the Extraordinaires Relationes aus

Allerley Orten and then in Danish, processes which involved personal judgment, decision, and action by the editor, and which contributed to the creation of images of persons or nations in the minds of his readers. (Ries 2001:253)

Ries stresses that their licenses did not allow them to carry out such important transformations of the texts, but rather to provide faithful versions of the originals (Ries 2001: 254). Sometimes the reports only needed a small change to offer a very different interpretation of the news event. For example, he quotes one particular text that translated a report "from Stockholm about how very pleased 'all (!) the king's subjects' were at his assumption of absolute power, in the Danish translation acquired an exclamation mark after the word 'all'" (Ries 2001: 255-256). Ries argues that it could be anything from a typographical error, an intentional addition or a Freudian slip (Ries 2001: 255-256), but also mentions that the editor had introduced an exclamation mark in other cases. It is remarkable how the news producer, by applying such a small modification to the original, could impose an entirely different approach to the news event.

\section{Foreign correspondents and foreign languages}

The history of journalism may have begun as accounts of people and events in foreign lands, which, as we have seen, involved translating and editing foreign texts rather than sending reporters to the foreign land itself. As newspapers increased their diet of domestic news, reporters proper began to occupy the positions of editors and translators. It was not until the 19 th century that the new companies began to employ foreign correspondents (Bourne 1887b: 136; Høyer 2003: 457). Writing in the 19th century, Bourne claimed that English newspapers prided themselves in having correspondents in foreign nations (Bourne 1887b: 237) such as France, Prussia and Russia. Sending journalists abroad was tantamount to the economic and political importance of the newspaper. This meant that a knowledge of foreign languages was regarded as necessary. Hohenberg mentions that in 1792 the Times of London advertised for "a gentleman who is capable of translating the French language" to be based outside the country (Hohenberg 1995: 3). However, a knowledge of languages was often superseded by the seniority of the members of the staff in order to decide on 
assignments abroad. This characterizes journalism even today. As Hess stresses, language and knowledge of the cultures where journalists are assigned is often secondary to experience within the company (Hess 1996: 80). He recalls an ad for the Washington Post where language skills were mentioned but emphasized that "we seek people who have a demonstrated track record over a number of years" (Hess 1996: 80). In other cases, a knowledge of foreign languages was regarded as a nuisance, as was the case with a French journalist who worked for the Paris Herald and whose articles had to be translated into English (Laney 1947/1968: 92).

To cope with the lack of languages, journalists developed various methods to translate news events. In his 600-page book about the profession, Robert Neal, a journalist himself, mentioned that one of the main challenges for foreign correspondents was the language of the country from where they reported. Among his recommendations, the following might be one of the most extraordinary ways in which the journalistic profession has attempted to solve the problem of communication when more than one language is involved:

A speech handled in this second-hand fashion had better be put largely in paraphrase rather than in direct quotation. Usually there are three or four ways in which a statement can be translated, each with a different shade of meaning, and the translator will give a version with the tone he himself favored rather than the slightly yet perhaps importantly different one the speaker had in mind.

If he arrived too late to catch an assistant, the reporter at least can take note on the times the audience reacted most vigorously and after the speech can ask an obviously intelligent listener to summarize those high spots. Not knowing the language doesn't mean not getting the story. (Neal 1940: 96)

Apart from this unusual approach, foreign correspondents began to rely on translations carried out by local staff employed by their company, either on a permanent or temporary basis. When working with languages in which "the expatriate correspondents were often not proficient, translation can also be a significant part of the work of local employees" (Hannerz 2004: 153). These writers might even produce material for the company that employs them as translators. In fact, doing translation work is regarded as valuable experience to become a reporter: "Doing a little bit of everything, but especially translating and interpreting, as a local employee in a sojourner correspondent's office can thus be an apprenticeship, a stepping-stone to a journalistic career" (Hannerz 2004: 153). Writing about the Tokyo office of The Washington Post, Hannerz mentions the case of a Japanese journalist who translated but also wrote for the newspaper. As journalism became a more respectable profession, activities like translation were gradually relegated to a secondary position, often at the same level as teacup washing: "Now there was also a new, very bright Japanese woman on the staff; she had been told that she could do some interviews and writing for the paper but must also be prepared to wash teacups" (Hannerz 2004: 153). On the other hand, if necessary, Hannerz notes, journalists and their companies can turn to commercial translation services. A good example of this is El País, the Spanish leading newspaper, whose commercial agreements with other international news companies allows the publication of major op-ed columns such as those written by Nobel Prize laureate Paul Krugman, rendered into Spanish by a translation company, whose work is duly acknowledged. However, this practice is unusual in news production, as we shall see in the next section. 
As the previous discussion demonstrates, in the 20th and 21st centuries foreign correspondents also rely on translation in one way or another. Major newspapers like the New York Times have the greatest number of reporters abroad (Kruglak 1955: 24). Hess stresses that some foreign correspondents work first as translators, like Linda Gradstein for the Washington Post (Hess 1996: 69) or Nick Driver (Hess 1996: 15). In fact, Hess suggests that much of the work done by foreign correspondents could be done from their headquarters (Hess 2005: 9, 128) because "given the world trend to outsourcing, could foreign correspondence by translation not be done at headquarters or through wire services?" (Hess 2005: 128). The foreign correspondents of some media are what Erickson and Hamilton label "the home-based foreign correspondent" or "the foreign correspondent with a global beat who lives within driving distance of his or her newpaper" (Erickson and Hamilton 2007: 138), that is, journalists who do not leave the country and whose main task is to translate and to edit the information gathered from various sources such as agencies or others news media. They rely on translation to do their job, in a more invisible way than foreign correspondents abroad, especially for papers like the Washington Post, because they no longer have permanent reporters outside their country of origin.

Journalists require knowledge of languages to perform their duties (Hess 1996: 79-86), either at home or abroad, for the major languages, whereas interpreters and translators can be required for lesser-known languages. A reporter working in Central Europe may have a working knowledge of German, but they are less likely to be able to work with Hungarian (Hess 1996: 84), or non-Western languages like Chinese, which can affect the production of a news story. For example, speaking of Bayard Taylor's reporting on the Taiping rebellion for the Tribune, Hohenberg writes that he had no command of the language and was not knowledgeable about the history and culture of the country so he was not aware of the importance of the story (Hohenberg 1995: 21). The event, which affected much of China in the mid-19th century, would eventually evolve in such a way that it meant the death of 20,000 defenders of Nanking. Taylor had to resort to local translators:

[t] he best he could do in preparing a few pieces for the Tribune was to visit Shanghai, obtain translations of some of the articles about the fighting in the local papers after he landed there, and put together what turned out to be the initial published account in the United States of the Taiping rebellion. (Hohenberg 1995: 21)

In other cases, journalists reporting from countries with limited freedom are forced to rely on translations provided by national services (Hachten and Scotton 2007: 70-71), but in these cases translators are rarely adequate (Legum and Cornwell 1978: 66). This becomes even more problematic when the reporting is done from countries under dictatorial regimes. Desmond recalls that during the first years of Communist rule in the USSR,

[i]f the correspondent required the assistance of a secretary, translator, courier or chauffeur, a native of the country had to be obtained through the usual channels. Such an assistance's own life then depended, perhaps literally, upon his or her first loyalty to the Communist regime. (Desmond 1982: 34)

So there were numerous reasons to doubt the accuracy of the translation.

Before we conclude this section let us underline that today a working knowledge of the language and culture is essential in the work of foreign reporters, in spite of 
the tendency of media companies to value seniority over everything else. Fortunately, Hohenberg believes, the importance of knowing the language and culture of the foreign country has gradually become part of the training programmes of many universities (Hohenberg 1995: 322). On the other hand, Leiter, Harriss and Johnson recommend a "broad knowledge of the English language" (Leiter, Harriss and Johnson 2000: 10) but also recognize the need for a foreign language - Spanish, for example. This language would facilitate the job of a reporter working even in the United States "where there is a large Latin American population, such as in southern Florida, the southwestern states or southern California" (Leiter, Harriss and Johnson 2000: 11). For his part, Hess stresses that "language proficiency should even be a factor in determining the most useful length of overseas assignments" because English "is not always the most useful or efficient way of communicating" (Hess 1996: 86). It is so much so that some news agencies like the AP might even pay for the language training of their employees (Hess 1996: 81). Thus, news agencies are returning to their origins.

\section{Recycled news}

Bielsa and Bassnett's recent study of news agencies explores the role of translation in the construction and dissemination of news texts from a sociological approach. As they point out, the first news agency was, indeed, a translation service. The French company Havas, created in 1832, was first and foremost a translation agency that transformed foreign texts for the French media (Bielsa and Bassnett 2009: 39; Bielsa 2010: 32) and, above all, for embassies, government agencies and banks (Hamilton and Jenner 2004: 309). Havas later became a full-fledged news agency under the name of Agence France Presse (Alleyne 1997: 6). Towards the late 19th century and early 20th century, Havas was regarded as a European monopoly from the other side of the Atlantic. The Americans believed that the news industry was in the hands of a few European news agencies, Reuters of England, Havas of Frances and Wolf of Germany (Kruglak 1955: 18). But American agencies were gradually gaining momentum. This was particularly true during World War I. Hohenberg recalls that "What they [US agencies] wrote [about the war] for their papers in substance was picked up and spread to the world either through wire services or syndicated arrangements or simply copied with acknowledgments of source" (Hohenberg 1995: 31). As we have seen, apart from the New York Times and its principal rivals, no other media could afford to send their own foreign correspondents to the conflict, so "American newspapers were able to get what little foreign news they published from their wire services - the AP, the UP, and the Hearst services, INS and Universal Service" (Hohenberg 1995: 154).

But, as we have seen, as the journalistic profession evolved from a linguistic transformation of foreign texts to a fully independent activity, translation was relegated to a secondary position, even within news agencies, where language transformations (both intra and interlinguistic) represented the core of the journalists' work. In his survey of foreign correspondents and news agencies in the 1950s, Kruglak found that even though journalists acknowledged the importance of languages in their profession, a working knowledge of a foreign language remained secondary, and news agency workers had the least fluency of those working in the profession, although "the news agencies, which in past years did not consider knowledge of 
foreign language important in assigning correspondents abroad, are changing their attitudes" (Kruglak 1955: 65). In fact, in the mid-20th century US news agencies had the greatest number of foreign correspondents: 169 as opposed to 69 sent by newspapers (Kruglak 1955: 72). These figures do not include the editor, "the translators, or the other members of the bureaus who are primarily engaged in preparing material for local consumption" (Kruglak 1955: 72).

After World War II the power of international agencies increased. Splichal reports that, during this period, five global agencies were the source of $80 \%$ of the information received by national news agencies and media throughout the world: AP, UPI, Reuters, AFP and TASS (Splichal 1984: 190). As we can see, the German agency Wolf disappeared from the picture, two American companies joined the top five, and Soviet TASS, which distributed news for the Communist bloc, became the fifth company in importance, although in countries like China things were somehow different. Since the relations with the Soviet Union were difficult, the Chinese relied on Western agencies. Desmond recalls that Communist newspapers in the country could not afford to subscribe to Reuters, so the practice was "to translate and rewrite news from foreign-language publications appearing in Hong Kong, Shanghai, and Tientsin, but often done without notable accuracy and with inevitable delay in the news report" (Desmond 1982: 187).

In fact, this trend is so widespread that news writers producing material for the major international news agencies "can expect to find their writing published, in translation, in a great many languages (although seldom credited to them personally)" (Hannerz 2004: 78). This can partly be explained because of the absence of international copyright laws that assert the rights of news writers, as they do in the case of literary writers, proving that the activity may have become a respectable profession but the value attached to the job of a journalist remains similar to the early days. Another important factor is the small number of US and European agencies that have become the main global news providers. For example, the principal Latin American publications depend on news wires by Reuters or the Associated Press (Ferreira 2006: 131).

Another important issue concerning the role of translation in news dissemination concerns the ideological manipulation of the texts by news agencies and news companies (Fortner 1994: 29; Ang, Hawkins et al. 2008: 26-27, 183), and what Conway calls in his paper for this volume "cultural translation." On the one hand, translation can allow news writers and editors to transform the content in order to suit the position of the company they work for. On the other, as English has become the dominant international world language, its linguistic supremacy also entails ideological imposition. In the second half of the 20th century, Legum and Cornwell reported on the problems of language choices for problematic terms such as "terrorism" (Legum and Cornwell 1978: 64) and on the problems of English in general (Legum and Cornwell 1978: 66). In their view, "the dominant role of the English language through the big Western agencies is a matter of concern to many Third World countries" (Legum and Cornwell 1978: 66). In fact, in his study of the four major Western news agencies, Boyd-Garrett (1980) concluded that they set the agenda for the smaller national ones, let alone regional and local media (Hamer 2006). For his part, van Ginneken believes that non-Anglophone national agencies have limited influence overseas, including those in major languages or belonging to major economies, such as the German, 
Spanish and Japanese ones. Even the French have complained about the loss of power of their own media (van Ginneken 1998: 46) to the benefit of Anglophone corporations. Van Ginneken notes, for example, that the Anglo-American monopoly was responsible for spoiling the traditional good relations between France and the Arab world during the Gulf war due to "allied misinformation" (van Ginneken 1998: 46). To counter the pernicious effects of the major agencies, there have been attempts to create alternative companies that take into account not only the interests of the AngloAmerican world. Splichal tells us the story of a pool of agencies created in the 1970s by a number of non-aligned countries in order to share information outside the five major agencies (Splichal 1984: 191-193). However, this venture was not sufficiently funded and the political turmoil that caused the collapse of communism also put an end to the pool, which had been led by a Yugoslav company. In other cases, smaller regional media may ignore the news gathered and translated by national companies and turned to their own sources (Ang, Hawkins et al. 2008: 26-27).

Leaving aside ideological considerations, translation poses linguistic and cultural difficulties to the journalist/translator (Ang, Hawkins et al. 2008: 80). Noblet, who worked for The Associated Press, has pointed out the need to be knowledgeable in other languages: "We deliver our news in five different languages - five languages other than English. And then, of course, any number of news outlets take our reports and translate them into other languages" (Noblet 2001: 55). He recognizes that working with other languages can be a problem. Recalling the O. J. Simpson's trials, Noblet mentions expressions like "playing hardball" and "bottom of the ninth" because they "don't translate to your audience in Budapest; you always have to fix those. Lou Gehrig's disease is only a disease in the United States. If you want to explain to somebody overseas, you have to give it its proper name, and then put (comma), 'which Americans refer to as Lou Gehrig' " (Noblet 2001: 58). One may even doubt whether the latter is at all necessary, but what is clear is that, as Bellos has pointed out, "the language operations performed in news agency work are perhaps of particular interest because they are predicated not only on the total invisibility of translation, but also on anonymity and impersonality" (Bellos 2009: 402).

\section{News in the Internet age}

As the 20th century drew to a close a new revolution was about to change the dissemination of information. What began as a platform to share military information (Curran and Seaton 2003: 239-240) gave way to a new phase of the post-industrial society that Bell (1973) had described in the 1970s. In the 21st century news circulates faster than ever before, but also more than ever before online journalism, news is about writing and rewriting agency stories. In his study of online journalism in five online German newspapers, Quandt found out that "most of the time, the journalists are just regrouping, editing, and fine-tuning news agency stories" (Quandt 2008: 86). In a few minutes they have to adapt agency material, with additional writing, editing and publishing (Quandt 2008: 86). Most of this material has been translated at some point or another.

Bruns claims that in the "post-industrial Internet age" (Bruns 2008: 174) media companies are being challenged by other less institutionalized news producers. He speaks of a movement from gatekeeping (the traditional concept that applies to the 
selection process of news material, discussed by Floros in this issue) to gatewatching (Bruns 2008: 176-180) as "the collective intelligence and knowledge of dedicated communities to filter the newsflow and debate salient topics of importance to the community" (Bruns 2008: 176-177). He refers to Wikipedia as an example of collaborative work (Bruns 2008: 179), where translation, adaptation and editing are uniquely related.

But the advent of the Internet and the appearance of convergence journalism, which implies the use of multiple resources and media to disseminate the news has not been unproblematic. Traditional journalists tend to look down on their online colleagues in the same way as writers had despised journalists in the early years of the profession. Researchers have reported tensions between print and online journalists in Ireland (Cawley 2008: 45-60), Argentina (García 2008: 61-75) and Belgium (Colson and Heinderyckx 2008: 143-154). In their study of journalistic practices in Belgian convergence newsrooms Colson and Heinderyckx argue that "despite their central location in the middle of the newsroom, online journalists were largely ignored" (Colson and Heinderyckx 2008: 148).

Another problem that has become more apparent in the era of digital information is the ideological bias of news companies, including those with a reputation for impartial reporting, such as the much-respected BBC, which has also been criticized for a lack of impartiality (Sturkey 2007: 95; Jaber and Baumann 2011). This has caused the appearance of alternative media that can provide an international audience with different perspectives of news events. One such venture is Al-Jazeera, the Qatari news service that challenged Anglophone media, first in Arabic, and from 2006 also in English: "Al-Jazeera's motive, in launching its own English-language international service, was inevitably to counter any influence of CNN among Anglophones" (Sturkey 2007: 125). State-owned and not uncontroversial, Al-Jazeera offers an Internet news portal in more than one language (English and Arabic), as do other national news media such as France 24 (in French, English and Arabic), the BBC (in 27 languages other than English) or Deutsche Welle (which offers a total of thirty languages). Translation is also at the basis of supranational portals like Euronews, which currently offers its news content in twelve languages.

However, this variety of languages and companies has also been challenged by many groups with the creation of alternative media such as the ohmynews in South Korea. Perhaps because, as Sturkey claims, "the world and its people may - in the near future, at least - be simply too heterogeneous to succumb completely to globalization" (Sturkey 2007: 125), new digital media can offer what traditional media cannot. Perhaps because, as Khang has shown, the complex interplay of the "subjectivities of institutional translators and editors" (Kang 2007: 224) does not meet the thirst for reliable news of all readers. Curran and Seaton suggest that the need for a new medium could give voice to many and diverse participants. But such a venture would take time and money, and translation would be one of the detrimental factors for the creation of such a medium as only an organization like the United Nations would be able to afford it (Curran and Seaton 2003: 401). Or, we may add, organizations which attract large numbers of volunteers.

Many other issues could have been mentioned in this brief overview of the relationship between news and translation. But irrespective of the changes that have characterized the evolution of journalism as a profession, translation has remained central: from the times when Dutch corantos were translated (physically and cultur- 
ally) into English to contemporary societies, where the news spreads digitally and globally in a much more rapid manner. The papers in this volume will contribute, we hope, to shed some light on the interconnection between these two processes, news production and news translation.

\section{REFERENCES}

Alleyne, Mark D. (1997): News Revolution: Political and Economic Decisions about Global Information. New York: St. Martin's Press.

Ang, Ien, Hawkins, Guy and DabBoussy, Lamia (2008): The SBS Story: The Challenge of Cultural Diversity. Sydney: University of New South Wales Press.

BAINBRIDGE, Cyril (1984): One Hundred Years of Journalism. London: MacMillan.

BAndle, Oskar (2005): The Nordic Languages: An International Handbook of the History of the North Germanic Languages. Volume 2. Berlin: Walter de Gruyter.

Baumann, Gerd, Gillespie, Marie and Sreberny, Annabelle (2011): Transcultural journalism and the politics of translation: Interrogating the BBC World Service. Journalism. 12(2):135142 .

Bell, Daniel (1973): The Coming of Post-industrial Society. A Venture in Social Forecasting. New York: Basic Books.

Beller, Manfred and Leerssen, Joep, eds. (2007): Imagology: The Cultural Construction and Literary Representation of National Characters. Amsterdam: Rodopi.

Bellos, David (2009): Jumping over the language barrier. Language and Communication. 29:401404.

Bellos, David (2011): Is That a Fish in Your Ear?: Translation and the Meaning of Everything. New York: Faber and Faber.

BIELSA, Esperança (2010): Translating news: a comparison of practices in news agencies. In: Roberto A. Valdeón, ed. Translating Information. Oviedo: Ediuno, 31-48.

Bielsa, Esperança and BAssnett, Susan (2009): Translation and Global News. London/New York: Routledge.

Bourne, H. R. Fox (1887a): English Newspapers. Chapters in the History of Journalism. Vol. 1. London: Chatto \& Windus.

Bourne, H. R. Fox (1887b): English Newspapers. Chapters in the History of Journalism. Vol. 2. London: Chatto \& Windus.

Boyd-Garrett, Oliver (1980): The International News Agencies. Beverly Hills: Sage Publications.

Brownlees, Nicholas (2006): Introduction. In: Nicholas Brownlees, ed. News Discourse in Early Modern Britain: Selected Papers of Chined 2004. Bern: Peter Lang, 7-14.

Bruns, Alex (2008): The Active Audience: Transforming Journalism from Gatekeeping to Gatewatching. In: Chris Paterson and David Domingo, eds. Making Online News. The Ethnography of New Media Production. New York: Peter Lang, 171-184.

Cawley, Anthony (2008): News Production in an Irish Online Newsroom: Practices, Process, and Culture. In: Chris Paterson and David Domingo, eds. Making Online News. The Ethnography of New Media Production. New York: Peter Lang, 45-60.

Clarke, Bob (2004): From Grub Street to Fleet Street. An Illustrated History of English Newspapers to 1899. London: Ashgate.

Colson, Vinciane and Heinderyck, François (2008): Do Online Journalists Belong in the Newsroom? A Belgian Case of Convergence. In: Chris Paterson and David Domingo, eds. Making Online News. The Ethnography of New Media Production. New York: Peter Lang, 143-154.

Conboy, Martin (2004): Journalism: A Critical History. London: Sage.

Conway, Kyle (2010): Paradoxes of translation in television news. Media, Culture and Society. 32(6):979-996.

Conway, Kyle and Bassnett, Susan, eds. (2006): Translation in Global News. Coventry: University of Warwick Centre for Translation and Comparative Studies. 
Curran, James and Seaton, Jean (2003): Power Without Responsibility. The Press, Broadcasting, and New Media in Britain. London/New York: Routledge.

Desmond, Robert Williams (1982): Crisis and Conflict: World News Reporting Between Two Wars, 1920-1940. Iowa City: The University of Iowa Press.

Dooley, Brendan and Baron, Sabrina A. (2001): The Politics of Information in Early Modern Europe. London/New York: Routledge.

Erickson, Emily and Hamilton, John Maxwell (2007): Happy landings. A defense of parachute journalism. In: David D. Perlmutter and John M. Hamilton, eds. From Pigeons to News Portals. Foreign Reporting and the Challenge of New Technology. Baton Rouge: Louisiana State University Press, 130-149.

Ettinghausen, Henry (2001): Politics and the Press in Spain. In: Brendan Dooley and Sabrina BARon, eds. The Politics of Information in Early Modern Europe. London/New York: Routledge, 199-215.

FaWCETt, Liz (2002): Why peace journalism isn't news. Journalism Studies. 3(2):213-223.

Ferreira, Leonardo (2006): Centuries of Silence. The Story of Latin American Journalism. Westport CT: Praeger.

Fishman, Mark (1980): Manufacturing the News. Austin: University of Texas Press.

Fortner, Robert S. (1994): Public Diplomacy and International Politics. Westport: Praeger.

García, Edgardo Pablo (2008): Print and Online Newsroom in Argentinian Media: Autonomy and Professional Identity. In: Chris Paterson and David Domingo, eds. Making Online News. The Ethnography of New Media Production. New York: Peter Lang, 61-76.

Hachten, William A. and Scotton, James F. (2007): The World New Prism: Global Information in a Satellite Age. Oxford: Blackwell.

Hamer, Martin (2006): Trading on trust: News agencies, local journalism and local media. In: Bob Franklin, ed. Local Journalism and Local Media: Making the Local News. London: Routledge, 210-218.

Hamilton, John M. and Jenner, Eric (2004): Redefining foreign correspondence. Journalism. 5(3):301-321.

Hannerz, Ulf (2004): Foreign News. Exploring the World of Correspondents. Chicago/London: The University of Chicago Press.

HARris, Michael (1987): London Newspapers in the Age of Walpole. A Study of the Origins of the Modern English Press. London/Toronto: Associated University Presses.

Hernández Guerrero, M. José (2009): Traducción y Periodismo. Bern: Peter Lang.

Hess, Stephen (1996): International News \& Foreign Correspondents. Washington: The Brookings Institution.

Hess, Stephen (2005): Through Their Eyes: Foreign Correspondents in the United States. Washington: Brookings Institution Press.

Hohenberg, John (1995): Foreign Correspondents. The Great Reporters and Their Times. New York: Syracuse University Press.

Høyer, Svennik (2003): Newspapers without journalists. Journalism Studies. 4(4): 451-463.

Jaber, Michael and Baumann, Gerd (2011): The BBC World Service in the Middle East: Claims to Impartiality of a Politics of Translation. Journalism. 12(2):171-182.

KANG, Ji-Hae (2007): Recontextualization of News Discourse. A Case Study of Translation of News Discourse on North Korea. The Translator. 13(2):219-242.

Kruglak, Theodore E. (1955): The Foreign Correspondents: A Study of the Men and Women Reporting for the American Information Media in Western Europe. Westport: Greenwood Press.

Laney, Al (1947/1968): Paris Herald. The Incredible Newspaper. New York: Greenwood Press.

Legum, Colin and Cornwell, John (1978): A Free and Balanced Flow. Report of the Twentieth Century Fund Task Force on the International Flow of News. Lexington: Lexington Books.

Leiter, Kelly, Harriss, Julian and Johnson, Stanley (2000): The Complete Reporter. Fundamentals of News Gathering, Writing, and Editing. Needham Heights: Allyn \& Bacon. 
Neal, Robert M. (1940): News Gathering and News Writing. New York: Prentice Hall.

Noblet, Kevin (2001): Producing and marketing news for the international audience. In: Tony Silvia, ed. Global News. Perspectives on the Information Age. Ames, Iowa: Iowa State University Press, 53-63.

O'Malley, Thomas (1986): Religion and the newspaper press, 1660-1685. In: Michael HarRis and Alan LeE, eds. The Press in English Society from the Seventeenth to Nineteenth Centuries. Madison: Fairleigh Dickinson University Press, 25-46.

Palmer, Jerry (2009): News Gathering and Dissemination. In: Mona Baker and Gabriela Saldanha Routledge Encyclopedia of Translation Studies. London/New York: Routledge, 186-188.

PoDKalicka, Aneta (2011): Factory, dialogue, or network? Competing translation practices in BBC transcultural journalism. Journalism. 12(2):143-152.

Quandt, Thorsten (2008): News Tuning and Content Management: An Observation Study of Old and New Routines in German Online Newsrooms. In: Chris Paterson and David Domingo, eds. Making Online News. The Ethnography of New Media Production. New York: Peter Lang, 79-97.

Ries, Paul (2001): The politics of information in seventeenth-century Scandinavia. In: Brendan Dooley and Sabrina Baron, eds. The Politics of Information in Early Modern Europe. London/New York: Routledge, 235-274.

Splichal, Slavko (1984): The role of third world news agencies in surpassing the one-way flow of news in the world. In: Jaswant S. Yadava, ed. Politics of News. Third World Perspective. New Delhi: Concept Publishing Company, 189-227.

Sturkey, Guy (2007): Balance and Bias in Journalism. New York: Palgrave.

TsaI, Claire (2006): Translation through interpreting: A television newsroom model. In: Kyle Conway and Susan Bassnett, eds. Translation in Global News. Coventry: University of Warwick Centre for Translation and Comparative Studies, 59-71.

VALdeÓn, Roberto A., ed. (2010): Translation in the Post-Industrialist Society. Across Languages and Cultures. 11(2).

VAN Doorslaer, Luc (2009): How language and (non-)translation impact on media newsrooms: the case of newspapers in Belgium. Perspectives. Studies in Translatology. 17(2):83-92.

van Doorslaer, Luc (2010): Journalism and translation. In: Yves Gambier and Luc van Doorslaer, eds. Handbook of Translation Studies. Vol. 1. Amsterdam/Philadelphia: John Benjamins, 180-184.

van Ginneken, Jaap (1998): Understanding Global News. London: Sage. 